\title{
Seeing like the people: a history of territory and resistance in the southern Ecuadorian Amazon
}

\author{
Diana Vela-Almeida ${ }^{1}$ \\ Norwegian University of Science and Technology, Norway
}

\begin{abstract}
The Cordillera del Condor in the Ecuadorian Amazon has been analyzed frequently in the literature of extractivism in Latin America, due to the current mining pressure on this territory. Mining is, however, the most recent in a long history of territorial transformations in the region. The production of territory in the Cordillera del Condor is the result of a complex historical accumulation of events, motivated by the political economy of the country that has transformed the people and its land. By studying the main events of state deterritorialization, this article examines multiple socio-spatial relations that occurred in the Cordillera del Condor. This article identifies three main events of state deterritorialization: (1) colonization and evangelization, (2) the EcuadorPeru war and (3) large-scale mining. The analysis illustrates how territory is constantly integrated into the economic and political rationality of the nation-state and discusses these transformations in line with the institutionalization of new forms of organization, legibility, commodification of nature and subjectification of people. In contrast, the study also illustrates how people inhabiting this space counteract state deterritorialization by deploying the same strategies as the state; reinforcing reterritorialization in their own terms. The article concludes by highlighting the agency of people to reshape state mechanisms in the struggle of defining a territory.
\end{abstract}

Keywords: state deterritorialization, reterritorialization, political ecology, Cordillera del Condor, Ecuador

\section{Résumé}

La Cordillera del Condor en Amazonie équatorienne a été fréquemment analysée dans la littérature sur l'extractivisme en Amérique latine, en raison de l'augmentation significative de l'activité minière. L'exploitation minière est cependant la plus récente d'une longue histoire de transformations territoriales dans la région. La production de territoire dans la Cordillera del Condor est le résultat d'une accumulation historique complexe d'événements. Celles-ci ont été motivées par une économie politique en mutation qui a transformé la société et le territoire. En étudiant les principaux événements de la déterritorialisation de l'État, cet article examine les multiples relations socio-spatiales qui se sont produites dans la Cordillère du Condor. J'identifie trois événements principaux de déterritorialisation de l'État: (1) la colonisation et l'évangélisation, (2) la guerre Equateur-Pérou et (3) l'exploitation minière à grande échelle. L'analyse illustre comment le territoire est constamment intégré dans la rationalité économique et politique de l'État-nation, et j'aborde ces transformations en lien avec l'institutionnalisation de nouvelles formes d'organisation, la lisibilité, la marchandisation de la nature et la subjectivation des personnes. En revanche, l'étude illustre également comment les habitants de cet espace contrent la déterritorialisation de l'État en déployant les mêmes stratégies que l'État; renforcer la reterritorialisation dans leurs propres termes. L'article se termine en mettant en évidence l'action des personnes dans la refonte des mécanismes étatiques dans la lutte pour définir un territoire.

Mots clés: déterritorialisation étatique, reterritorialisation, écologie politique, Cordillera del Condor, Equateur

\footnotetext{
${ }^{1}$ Dr. Diana Raquel Vela Almeida, Postdoctoral Fellow, Department of Geography, Norwegian University of Science and Technology (NTNU), NO-7491 Trondheim, Norway. Email: diana.velaalmeida "at" ntnu.no. This work was supported by the National Secretary of Higher Education, Science, Technology, and Innovation of Ecuador - SENESCYT. I am grateful to all participants, individuals and organizations who provided valuable information and supported fieldwork in Ecuador. I also thank Jeremy Rayner, Vijay Kolinjivadi and two anonymous reviewers for constructive revision of previous drafts.
} 


\section{Resumen}

La Cordillera del Cóndor en la Amazonía ecuatoriana ha sido ampliamente analizada en la literatura sobre extractivismo en América Latina debido a la actual presión minera sobre este territorio. Sin embargo, esta discusión es solamente la más reciente en una larga historia de transformaciones territoriales en la región. La producción de territorio en la Cordillera del Cóndor es el resultado de una compleja acumulación histórica de eventos, motivada por la economía política coyuntural del país que ha transformado a las poblaciones y sus tierras. Al estudiar los principales eventos de la desterritorialización estatal, este artículo examina las múltiples relaciones socioespaciales sucedidas la Cordillera del Cóndor. Este artículo identifica tres eventos principales de desterritorialización estatal: (1) la colonización y evangelización, (2) la guerra Ecuador-Perú y (3) la minería a gran escala. El análisis ilustra cómo el territorio se integra constantemente dentro de la racionalidad económica y política del estado-nación y analiza estas transformaciones alineadas con la institucionalización de nuevas formas de organización, legibilidad, mercantilización de la naturaleza y subjetivación de las poblaciones. En contraste, el estudio también ilustra cómo las personas que habitan este espacio contrarrestan la desterritorialización estatal mediante el despliegue de las mismas estrategias del estado; reforzando la reterritorialización bajo sus propios términos. El artículo concluye destacando la agencia de las poblaciones para reformular los mecanismos estatales en la disputa sobre la definición de un territorio.

Palabras Clave: desterritorialización estatal, reterritorialización, ecología política, Cordillera del Cóndor, Ecuador

\section{Introduction}

The Cordillera del Condor in the Ecuadorian Amazon has been discussed in the literature on extractivism in Latin America because of the current prominence of large-scale mining projects. Most discussions of the political ecology of mining in Ecuador have focused on socio-ecological conflicts, negative environmental impacts, and the problematic of mining and development in the territory (Chicaiza and Yanez 2013; Sacher 2011; van Teijlingen et al. 2017; Vela-Almeida 2018; Warnaars 2013a, 2013b). This article contributes to the emerging political ecology discussion of the "eco-territorial turn" (Svampa 2019), suggesting that extractivism in its current form needs to be contextualized within the longer history of political economy and the territorialization practices that have resulted in struggles for control of resources. Beyond large-scale mining activity, there is a long history of territorial transformations in the region as a result of broader national political processes of state-building as well as local reconfigurations of socio-spatial relations (Vela-Almeida 2018). A historical analysis of the Cordillera del Condor allows an understanding of how territory is constantly integrated into the economic and political rationalities of the modern state at particular moments in time (Kohl and Farthing 2012; Vandergeest and Peluso 1995). In presenting this history, I discuss territorial transformations in line with strategies for state deterritorialization, which are here understood as practices that render space subject to abstract forms of power of the state, a process famously described by James Scott (1998) as "seeing like a state." At the same time, these practices incite resistance, understood as reterritorialization (i.e. "seeing like the people"), a vis a vis response to political and economic changes enacted in the process of reclaiming control over land and resources (Haesbaert 2013).

By emphasizing a diachronic, productive process by which territories are built and resources controlled, this article describes historically-layered contexts and sets of relations between the state and the people inhabiting the Cordillera del Condor. This analysis considers the mechanisms which serve to enhance deterritorialization through state intervention and reterritorialization through resistance. Using the definitions provided by Deleuze and Guattari (1988), deterritorialization and reterritorialization are conceived as concomitant and inseparable forces of human agency that illustrate the multiplicity of relations and subjectivities in dispute over space (see also Haesbaert and Bruce 2002). As such, processes of deterritorialization are part of the dynamics of capitalism and state-making that establish a new set of relations in a particular territory. Strategies of state deterritorialization that will be analyzed in the history of the Cordillera del Condor include: the institutionalization of new socio-spatial organization; legibility of land and resource use; the commodification of nature; and subjectification of cultural identities. This article also highlights how strategies to confront state interventions have emerged as reterritorialization responses that challenge the state logic of territorial domination. In doing so, I illustrate how resistance can be considered as mirror strategies to resist state deterritorialization as these practices strengthen socio-spatial relations. 
For this analysis I conducted participatory observations and twenty-five semi-structured interviews of key actors in the Cordillera del Condor. Interviews were completed between 2014 and 2017 and included inhabitants and representatives of the local governments, provincial and communitarian Indigenous organizations and civil society organizations. Interviews covered questions related to economic transformations and resource use, development projects and the historical events that transformed the Cordillera del Condor. Additionally, I conducted an extensive literature review related to the historical transformation of the Cordillera del Condor, mainly covering literature about the $19^{\text {th }}, 20^{\text {th }}$ and $21^{\text {th }}$ centuries. This review included documents from the Shuar studies by the Salesian missionaries, together with the work of Steven Lee Rubenstein, Elke Mader, and more recent studies on extractivism by Gloria Chicaiza, Esben Leifsen, Luis Sánchez, Karolien van Teijlingen and Ximena Warnaars. The discussion presented in this study is based on the information emerging from all the different sources. In what follows, I argue that territory is constantly being deterritorialized and reterritorialized in a manner that serves contingent economic interests in the country and in line with the political rationality of the nation-state. I identify three main events of state intervention that have resulted in patterns of state deterritorialization and simultaneous reterritorialization in the Cordillera del Condor: (1) colonization and evangelization, (2) the Ecuador-Peru war and (3) large-scale mining. I contextualize existing historical territorial changes to discuss the use of similar state mechanisms employed by the inhabitants of the Cordillera del Condor that serve to resist and reshape state-developed mechanisms for territorial control. I conclude by highlighting the agency of these people to reshape state mechanisms in the negotiation process of constructing territory.

\section{Deterritorialization and "seeing like a state"}

Deterritorialization processes result from emerging power structures that create new forms of sociospatial relations (Brighenti 2010; Delaney 2005; Sack 1986). This assumption starts with the notion that territory per se is not a fixed and stable configuration of social relations; instead, it is produced by the accumulation of contextual political, social and economic relations reflected spatially and temporally (Forsberg 2003; Raffestin and Butler 2012). As Lefebvre and Nicholson-Smith (1991) put it, the production of territory is associated with turning space into territory by the reinforcement of cultural meanings, institutions and subjectivities. Although there is an extensive genealogy for the concept of territory (Vaccaro et al. 2014), current discussions are dominated by ideas of control and governmentality (Agnew 2013) and materialist approaches to the production of territories (Brenner and Elden 2009; Lefebvre 1991), as well as processes of accumulation and dispossession (Harvey 2005). In that line, redefining territory as being continuously deterritorialized illustrates how sociopolitical decisions permit the state, and those being governed, to generate new forms of socio-spatial organization, while at the same time, explains the ways by which people transforms meanings, material practices and subjectivities in their process of reterritorialization.

In looking at the way territory is essential for state-building, it is important to examine how the state uses territorial strategies to exercise control and regulate land-based resources in line with neoliberal logics (Agnew 2013; Radcliffe and Westwood 1996). States legitimate their claims on a particular territory by employing natural resources to sustain economic development in a context of integration within a global market economy (Kohl and Farthing 2012; Vandergeest and Peluso 1995). In this manner, state deterritorialization produces new forms of socio-spatial organization established as mechanisms to increase state dominion over resources and people (Haesbaert and Bruce 2002; Robbins 2001; Thomas and Hodder 2001). Practices of state deterritorialization can be analyzed using the lens of governmentality (Agnew 2013) in which new forms of socio-spatial organization are seen as the product of strategies for further control (Foucault 1991). Governmentality then represents a set of practices for entrenching state control couched in a centralized pursuit of optimizing wellbeing for the population. Such practices reconfigure socio-spatial organization through the emergence of new institutions for better managing social patterns of behaviors and to strategically intervene and control relations between people, resources and means of subsistence (Ferguson and Gupta 2002; Huxley 2007).

A common way to understand state deterritorialization has been developed by Scott (1998) in his popular book Seeing like a state: how certain schemes to improve the human condition have failed. In his treatise, Scott 
argues that states strive to make territories "legible" in order to develop more efficient mechanisms for territorial planning and regulation of resources use. In doing so, states reduce and simplify the heterogeneity of peoples, territories and knowledges. Seeing like a state points to the different mechanisms for state deterritorialization that occur in a specific space to align to state rationality. As such, the modern state establishes new procedures for claiming territories using the strategies described above (Braun 2000; Huxley 2007; Vandergeest and Peluso 1995). In the historical recounting of the Cordillera del Condor, I detail these strategies in order to contextualize them with processes of state deterritorialization. Specifically, these practices can be described as changes in demographic rearrangements, definition of new politico-cultural subjects, property regimes, land use, and the consolidation of new market economies for greater control of the region.

\section{Reterritorialization as state 'mirror strategies'}

Although the history of the Cordillera del Condor shows evidence of state deterritorialization, this form of "seeing like a state" (e.g. Scott 1998) still assumes the state to be a monolithic entity without considering the variegated and complex relationships existing between state and the society (Gupta 1995; Li 2005). For instance, social resistance and citizen demands have always served to reshape state policies by inserting new claims to satisfy social demands and, ultimately, to renegotiate the way a territory is built (Haesbaert 2013). Moreover, very often, when discussing state deterritorialization "populist discourses" (Adger et al. 2001) tend to portray communities as passive victims of, or fierce opponents against, state or capital projects that destroy their ways of life. Such portrayals fail to recognize the complex ways that state neoliberal policies become locally reshaped, hybridized and embedded in the lives of people (Castree 2007; Higgins et al. 2012; Cleaver 2012).

There is a vast literature on resistance and how people have challenged hierarchical structures of domination and state deterritorialization in Latin America (Bebbington et al. 2008; Boelens et al. 2012; Esteva 2010; Zibechi 2012). In this article, I use history to illustrate the "socially diversified contents of human agency" to counteract state intervention (Armiero 2008: 59). Economic, political, cultural and social relations between the people inhabiting the Cordillera del Condor and the state are explored by examining historical changes through a conflict-based approach of "seeing like a protester" (Armiero 2008). In other words, throughout the seemingly smooth history of state deterritorialization processes, there is a parallel history of reterritorialization in which inhabitants reclaim their particular meanings of territory and ways of living. While the notion of resistance has been conceptualized elsewhere as "weapons of the weak" (Scott 1985), as clientelist relations (Shue 1994), the destruction of property or poaching (Peluso 1992), as vernacular statecraft (ColloredoMansfeld 2009) and as new forms of organization (Zibechi 2012), in this article reterritorialization processes are interpreted as hybridized 'mirror strategies' of state deterritorialization, in which people use state-developed institutions of legibility, commodification and subjectification to reclaim their territory, to retain use and control of resources or to resist state impositions. As such, 'mirror strategies' respond to state deterritorialization by using those same state mechanisms as part of relational forms of territorial resistance.

People have reshaped state mechanisms to purposefully reterritorialize their land. These acts of resistance are subsequently adopted as "counter-work" governance (Ferguson 1994; Li 2007). While mechanisms for state deterritorialization can be considered as strategies for controlling the politicization of territorial governance by the state, mirror strategies emerge in the process of re-politicizing knowledge, meanings, territorialities, subjectivities and formal instruments for governing. They define alternative agendas that contest decision-making and reassert control and access to resources. Reterritorialization then takes shape as a consolidation of contested notions of territory that allow people to control resources and exercise decisionmaking power to define socio-spatial organization (Elden 2010; Lefebvre and Nicholson-Smith 1991; Lefebvre 1991; Little 2001, 2018; Sack 1986). As such, both deterritorialization and reterritorialization processes in the Cordillera del Condor have been shaped by global and national historical moments coming together and influenced by contesting economic, political and social apparatuses. 


\section{The territorial history of the Cordillera del Condor}

To understand the deterritorialization and reterritorialization processes in the Cordillera del Condor, it is necessary to engage with the historical accounting by which territory has been ontologically produced. For the purposes of this article, this means examining the everyday practices, institutions, discourses and imaginaries where territoriality has been continuously contested over time. While I want to highlight the state as a disaggregated apparatus, where a monolithic entity can't be seen as unified (Gupta 1995; Sivaramakrishnan 1999), my aim is not to explore the multilayered heterogenous (and also contradictory) relations of state organization, but rather to emphasize the nuanced mechanism by which the central state overtook the control of a territory and created new meanings and subjectivities for people and their land. I also would like to clarify that in a diachronic analysis, the state I refer to alters over time. Clearly, today's state is not the same apparatus that constituted a state in the $19^{\text {th }}$ or $20^{\text {th }}$ centuries but a contextualized organization produced by the continuous demands of the political economy over time.

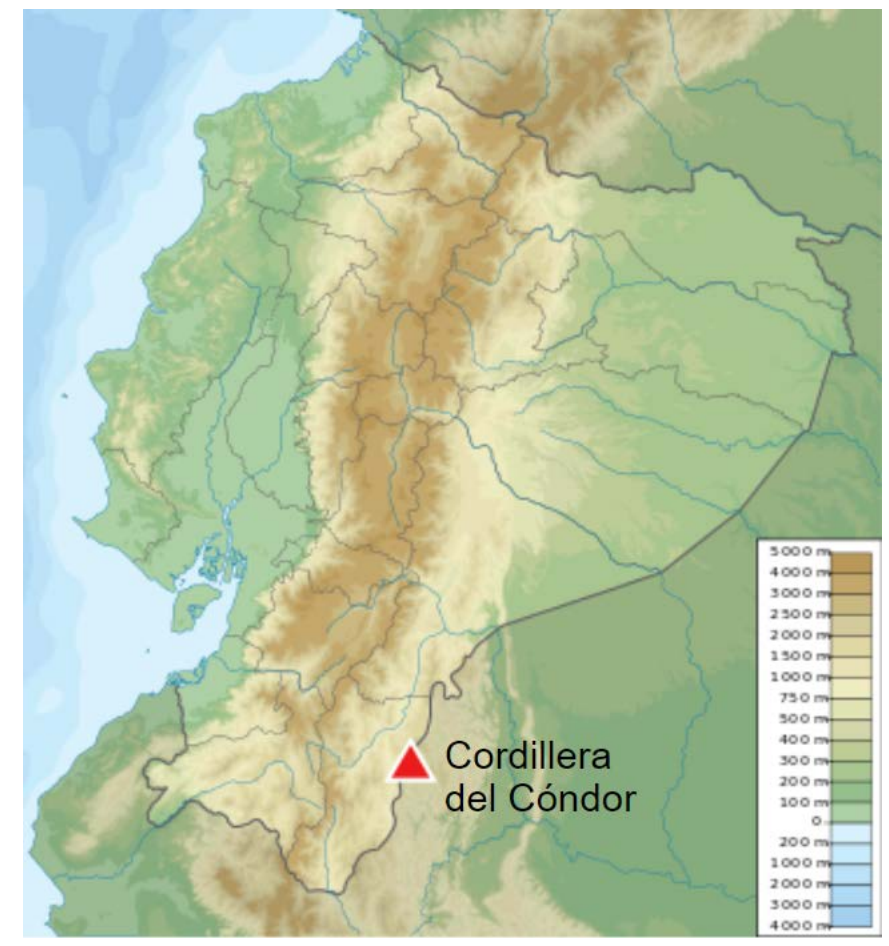

Figure 1: Cordillera del Cóndor, Ecuador. Source: Wikipedia.

For most of the $19^{\text {th }}$ and $20^{\text {th }}$ century, the Amazon was conceived as an inhospitable and dangerous place as much as a romantic haven of wild and rich nature. This pare of the the Amazon was officially recognized as part of Ecuadorian territory in 1861, however its actual incorporation into national territory repeatedly failed because the state was simply absent in the region (Little 2001; Restrepo 1993). For the state, the Amazon was problematic due to the lack of mechanisms to integrate it into the national economy and the constant struggle to protect national borders (Cleary 2001; Little 2001). But once interest in national and international markets emerged in the middle of the $20^{\text {th }}$ century, the Amazon became a place of development opportunities (Sawyer 2004). I identified above three main events of state intervention: colonization and evangelization, the war with Peru, and the arrival of large-scale mining. These historical events have resulted in the production of territory that accommodates the interests of the state and its economic power. An economic and political agenda has led to the consolidation of state rule in the Cordillera del Condor that has resulted in resistance and reterritorialization in response. 


\section{Colonization and evangelization}

The Cordillera del Condor was traditionally part of the territory inhabited by the Indigenous Shuar peoples in the Ecuadorian southern Amazon. The Shuar lived in dispersed autonomous households and had relatively loose centralized, hierarchical social systems (Salazar 1977). Resources were open access; space was physically unbounded, and dispersion was defined by social negotiation and warfare against other Shuar groups (Rubenstein 2001). Colonization of the Amazon did not reach Shuar territories until the late 1800s when Catholic missionaries arrived in the region and established missions (Mader 1999; Rubenstein 2001). Since then, there have been two main external forces that initially re-constituted the character of the Cordillera del Condor: the state and the church. Each assumed a specific role in defining socio-spatial relations in their effort to control territory (Rubenstein 2001). They introduced new institutions for territorial control, demographic rearrangements, the introduction of legal property regimes, as well as the integration of land into the market economy.

The government relied on the work of missionaries to foster large-scale evangelization, to incorporate the Shuar as Ecuadorian citizens and to reclaim the Amazon region as part of the nation by identifying new streams of labor and resources for capital accumulation (Erazo 2013; Mader 1999; Rubenstein 2001). As the state did not possess the resources to establish a presence in the territory, it relied on the church to incorporate the Shuar and their territory into the market economy as a means to exert permanent control over people and their land. This took place through the provision of the first public services, such as hospitals and schools as well as roads connecting the Southern Amazon with the Andes (Rubenstein 2001).

When new missionaries arrived at the beginning of the $20^{\text {th }}$ century, they played a crucial role in further embedding the Cordillera del Condor into the nation-state, as they opened the door for the establishment of new settlements. In 1964, with the National Land Reform and later in 1978, with Law 2092 for the Colonization of the Ecuadorian Amazon Region, the government stimulated internal migration as a national priority to increase occupancy of "empty and idle lands" in a distant and wild inhabitable space. The land reform and associated incentives for expanding the economic frontier to the Amazon encouraged poor landless settlers locally known as colonos and henceforth called mestizos from the coast and the Andes to seize large parcels of land among the Shuar population. Mestizos were generally landless peasants from the Sierra with Indigenous roots who migrated to the Amazon during the second half of the $20^{\text {th }}$ century. They had been marginalized themselves, and initially, Shuar and mestizos developed peaceful relationships based on trade of goods in return for land. However, while mestizos believed that such exchanges were social contracts that established property rights, the Shuar believed that trading partnerships were only temporary and that mestizos would eventually move to other lands (Rubenstein 2001).

Economic development stimulated further investment in infrastructure and facilitated the integration of the southern Amazonian region into the national economy (Báez Rivera et al. 2004; Rubenstein 2001). This could only happen by developing legible mechanisms for the assimilation of the Shuar territory into the nationstate. The state used a broad consolidation of managerial and procedural practices related to the rationalization and subsequent standardization of local and traditional worldviews into expert national planning, as well as new legible spatial practices of reading territory with greater simplification and standardization (Braun 2000; Robbins 2001; Thomas and Hodder 2001). As part of making the territory legible, land reform resulted in forest clearance endorsed by the state. New land uses and deforestation intensified land tenure conflicts as nature was appropriated for timber extraction, agriculture, and cattle production. The meanings of nature changed as it was represented as land for ranching and pasture conquered and appropriated by new settlers who help incorporating the Amazon into the Ecuadorian nation-state. By the 1930s, the Shuar had lost a considerable amount of land to mestizos, as an increasing number of new settlements made land increasingly scarce and resulted in rising tensions between these two groups. Since the state, with its weak presence, was unable to resolve disputes, the church together with the mestizos leveraged the market economy to maintain peaceful relations among the Shuar, with missionaries further extending acculturation processes and persuading the Shuar to abandon perceived "savage" practices and embrace their involvement in the market economy. The Shuar were then encouraged to demonstrate that their lands were "productive" for agriculture and cattle in order to claim legal ownership of the land (Warnaars 2013a). 
Territorialization and subjectification are indivisible, and so the recognition of actors' identities was transformed along with the transition to new socio-spatial forms of organization. Processes of evangelization together with colonization generated crucial socio-spatial and identitarian transformations. The Shuar reorganized space by abandoning itinerant practices and creating nucleated settlements called centros of five to thirty families. These constituted the means to claim land rights secured by the state (Rubenstein 2001). In 1935, the Ecuadorian government created a Shuar reserve to regulate increasing mestizo settlements and granted the jurisdiction of the land and its inhabitants to the Salesian missionaries to further embed state regulatory control over land (Rubenstein 2001; 2007). In 1964, representatives of the centros located in the Morona Santiago Province created the Shuar Federation (FICSH) as an administrative jurisdiction for the Shuar territory to generate greater political influence in the area through legal land tenure. In 1969 missionary administrative control over Shuar land was ended when the Shuar Federation and the Ecuadorian government signed an agreement that the Federation would assume the administration and management of the Shuar reserve, while promoting the growth of cattle production in their lands. The demand for communal land responded to the fact that Shuar territory was not recognized in the governmental project through the newly defined institutions governed by mestizos, such as the Ecuadorian Institute for Agrarian Reform and Colonization and the provincial and municipal governments that the Shuar were not part of. Importantly, while the historical experiences of the Shuar population living in the Morona Santiago and Zamora Chinchipe provinces differ in terms of colonization, relations with missionary orders and the state, and also their political positions regarding resource use; the populations living in the Cordillera del Condor share common experiences of territorial changes.

While legal provisions protected mestizo land use practices, the Shuar soon realized they needed to use the same legal mechanisms and dependence on economic activities to reclaim their land and build a new form of territoriality. The creation of the centros can be considered a way of contesting land seizure and land appropriation as the Shuar responded to modernization measures to protect their land. These new "modern" practices caused many Shuar to claim land rights as a response to the increase in mestizo settlements (Rubenstein 2007). Eventually, after the creation of the Shuar Federation, the centros obtained more secular characteristics with increasing market relationships, which in turn allowed the Shuar to have more political independence over local affairs and to develop a collective awareness to defend the newly defined Shuar land (Rubenstein 2007). This could also be interpreted as Shuar land being enclosed into centros, and to a certain extent reducing their previous nomadic practices. However, centros became the focus of all social activity and Shuar leaders soon assumed a more politicized role in developing collective awareness to defend the newly defined Shuar territory from encroachment by mestizos (Rubenstein 2001). In 1969, the Ecuadorian government, with the recognition of the FICSH, also recognized a 'global system' of ownership as a form of commons in which land could only be bought, sold or inherited within the Shuar communities, a form of property right that protected land seizure and privatization (Rubenstein 2001).

Van Teijlingen and Warnaars (2017) explain that the rejection of Shuar territoriality can be also explained by powerful ethnocentric narratives that formalized cultural identities for both the mestizos and the Shuar. The Shuar were transformed from "wild tribes" that required education and evangelization to Ecuadorian citizens integrated to the nation-state. At the same time, Rubenstein (2001) argues that the creation of the Shuar Federation marked the development of a Shuar identity as a single culture characterized by the de facto incorporation of the Shuar into the Ecuadorian state and constituting them as a critical instrument for extending state influence and territorial administration. In Rubenstein's (2001: 264) words, "what is from the Shuar perspective inclusion in a larger entity is from the Ecuadorian perspective an extension into new geographic and social space" (emphasis in original). As such, identities are constructed in a historical and territorial context (Hale 1997; Radcliffe and Westwood 1996).

The Shuar identity has constantly been transformed by re-defining what citizenship means, as well as by changing the social connections to the land that the Shuar have established. They were historically not a cohesive cultural group as their lives were marked by territorial tensions and warfare. However, the creation of the Shuar reserve in 1935, together with the establishment of the Shuar Federation, unified previously isolated Shuar households. Moreover, their institutional capacity was harnessed to create a sense of identity as a Shuar ethnicity that was spatially and legally bounded (Rubenstein 2001). It was clear during the interviews that as part of their cultural imaginary, the Shuar did not feel themselves to be victims nor passive recipients, but rather 
warriors who negotiate different strategies to protect their territory. During one interview, the president of a centro Shuar mentioned "we are brave, we are warriors, we will protect our land." The Shuar claim they were colonized but never conquered; neither by the Incas, nor by the Spaniards (Mader 1999). This spatial transformation made possible a new historical consciousness for the Shuar as their politico-cultural identities became shaped in the process of contestation and development of their territoriality, based on their rights and their belonging to the place. Subjectification thus involves the continual construction of political-cultural identities based on the self-recognition of actors involved in the production of the territory (Peluso 1992; Perreault 2002).

\section{The Ecuador-Peru war}

The Amazon as a whole has been increasingly mapped since the $19^{\text {th }}$ century; boundaries have been set and territorial control divided among Amazonian countries. This process of defining territorial boundaries for nation-states occurred independently of the territorial relations, kinship and resource use among Amazonian Indigenous peoples (Little 2001). 'Legibility' involved national planning and the generation of technocratic knowledge for land use and the imposition of formal property regime boundaries. As Scott (1998) argues, this is accomplished through functional mapping and by unifying indicators favored by the state and corporations such as the economic valuation of resources. Nature was also incorporated into the national economy by prioritizing particular aspects of its materiality. The commodification of nature occurs when certain materialities become the iconic identification of a place, hence its dominant value. Thus, some uses of natural resources are seen to better optimize commercial values of strategic importance to the state. Davidov (2014) calls this action "metonymic materiality", in which one materiality is valued more than others, and commodified. The discovery of oil in the $20^{\text {th }}$ century motivated the governments of Peru and Ecuador to grow industrial development in previously remote areas, marking the beginning of a proactive involvement of the state in the Amazon (Marcella 1995; Svampa 2008). Nature's new materiality became typified as "black gold", a resource that grew into the promise of prosperity for the whole country. When oil became commodified the totality of nature was atomized into a single natural resource subject to extraction. This has continued with the current boom in mining.

Ecuador and Peru began oil exploration with the help of transnational corporations. The mission of finding oil soon generated conflict over the national borders between the two countries and therefore contestations over the national ownership of the Cordillera del Condor (Marcella 1995). Government land claims targeted the Amazon as a strategic economic frontier, privileged defense spending in Ecuador. This was one of the motives for a war with Peru in 1941 (Kimerling 2006). In 1942, Ecuador ceded Amazonian land to Peru and signed the protocol of Rio de Janeiro. After secession, the new boundary between Peru and Ecuador aligned with the oil concessions given to Standard Oil of New Jersey and Royal Dutch Shell of the Netherlands (Little 2001; Rubenstein 2001). However, the dispute over the location of national frontiers was unresolved, with Ecuador disputing the protocol (Viatori 2016). This led to tensions in subsequent years that resulted in a new war in 1995.

During the first war in the 1940s the Amazonian region played a central role in forming national unity (Little 2001; Radcliffe and Westwood 1996). The discovery of oil made the Amazon a place of economic value, but also of symbolic value for national pride (Sawyer 2004). During the war period, the Shuar developed a special sense of pride towards the defense of the Ecuadorian national frontier. This nationalistic drive was key in the defense of the Cordillera del Condor during the second war (1995) because many Shuar served in the Ecuadorian Army. The Shuar were distinguished in battle and their 'national heroism' became impregnated in the imaginary of them as Ecuadorian citizens protecting national sovereignty and their own identity as warriors. The Shuar saw Peru's invasion as a threat to their territory, and it strengthened their identitarian nationalism as Ecuadorian citizens in relation to rights and responsibilities on their territory. The state project requires citizens to assume a national political identity and this new process of Shuar subjectification could also be read as an accommodation of Shuar territoriality to the national interests, in the aim of protecting national boundaries.

With the end of the second war in 1998 and the signing of the Agreement of Brasilia, Ecuador and Peru settled on an Agreement for Border Integration, Development and Neighborhood predicated on developing projects for irrigation, agriculture, energy, tourism, and sustainable exploitation of mineral resources. Soon after 
the war, strong environmental interests in the Amazon appeared due to the emergence of the international environmental movement and the international conservation agenda grew in the 1990s, particularly through the establishment of protected areas (Fontaine 2006). A key component of the agreement between Ecuador and Peru was the establishment of a 2,540 hectare "peace park" protected area for conservation called Parque Binacional El Condor (Chicaiza and Yanez 2013). The rationale for the peace park was centered on rehabilitating environmentally vulnerable zones affected by war and working to promote shared interests in conservation (Marton-Lefevre 2007). Political interests were mobilized to conserve the Cordillera del Condor due to its unique biodiversity (Fontaine 2006; Martin 2011), and more recently, through the establishment of conservation initiatives as part of the global carbon market. Nature again was commodified as part of a new materiality centered on the protection of a biodiversity hotspot, an agenda dominated mainly by international conservation NGOs. These narratives prioritized a meaning of territory based on the conception of biodiversity as the most important materiality of the territory (Davidov 2014).

The establishment of the Parque Binacional El Condor as a protected area changed the form in which the territory was overseen, since legible control of land use was formally managed by administrative organs from Quito together with environmental NGOs, with no Indigenous participation or consultation (Chicaiza and Yanez 2013). Initially, Indigenous communities and organizations worried that the conservation areas would overlap with their ancestral territories but later they were convinced that they would benefit from the legal establishment of the protected park. Indeed, Shuar supported the initiative as they saw it as an opportunity to exercise their right to self-determination (Warnaars 2013a). However, the delimitation of protected areas contradicted the rules established for land use by Indigenous peoples, by perniciously ignoring their ways of living (Warnaars 2013a). This resulted in confrontation with the Shuar who believed that by collaborating in the defense of national territory during the war with Peru, they would gain formal recognition (and hence legal protection) of their extended territories through the management of newly-formed conservation areas (Warnaars and van Teijlingen 2017). Even after Indigenous peoples gained legal recognition in Ecuador, their territorial rights were systematically disregarded by the same state that granted them rights (García Labrador and Ochoa 2020). Even today, the state fails to include Shuar communities in the demarcation of territories and in defining boundaries that delimit mining concessions.

Despite these obstacles, the Shuar have leveraged conservation initiatives to retain administrative and economic control of their territories. In 2003 several Shuar centros in the Cordillera del Condor established the Governing Counsel of the Peoples Shuar Arutam (CGPSHA) to pressure for their territory to be recognized. The Shuar Arutam is a second tier Shuar organization formed by 47 centros with 13,000 people and covering an area greater than 200,000 hectares (Pueblo Shuar Arutam 2019). Their objective is to organize the defense and the collective culture of the Shuar. In 2008 the Shuar Arutam became the first organization to acquire an agreement for conservation payments, involving 27 Shuar communities, 100,000 individuals and 200,000 hectares of forest. In total, the organization received an annual economic incentive of US\$452,000 (CDES 2017; UICN 2012). This agreement was part of the Socio Bosque program, promoted by the national government to respond to the principles of REDD+ initiatives and provide incentives for the conservation of native forest to reduce deforestation rates and protect ecosystems. The Shuar Arutam view conservation as a way to finance health, education, economic activities and governance expenditures. During an interview, a member of the Shuar Arutam organization explained "we do not want extraction of our resources. We can improve the economies of Shuar families through conservation." Yet, they do so through strategies that commodify nature by accepting a price for the conservation of their land and restrictions on land uses. This decision also has led to internal conflicts over the distribution of the income generated by Socio Bosque. These 'mirror strategies', or 'seeing like a state', employ market approaches organized by the state to gain economic control of their land, but ultimately serve to commodify nature. This illustrates that in contrast to a romanticized imaginary, livelihoods have long been dependent on cash crops, livestock production, national defense and increasingly precarious labor in the extractive industries. Yet, these livelihoods remain linked to the land and the use of resources with the knowledge of past experience reshaping state deterritorialization processes. 


\section{Large-scale mining}

Biodiversity conservation Initiatives have not been successful in preventing the establishment of largescale mining projects in the region. Indeed, the continuous focus of the central government on supporting extractive activities has resulted in reduced room to consolidate conservation projects or the ecologically sustainable initiatives of environmental NGOs. The history of mining in the Cordillera del Condor had its beginnings with explorations promoted by the Mining Law of 1991 and subsequent neoliberal policy advice from the World Bank (Cisneros 2011). In the 1990s, several companies were tasked with prospecting in the Cordillera del Condor and in the early 2000s, the Canadian Company Corriente Resources (and later its Ecuadorian branch Ecuacorriente-ECSA) and Kinross-Aurelian arrived in the Cordillera del Condor to further advance exploration and drilling. The national interest in mining as a priority for development was consolidated in 2009 with a Mining Law established at the peak of the Latin American commodity boom, with the backing of President Rafael Correa. At that time, Chinese investors showed interest in extractive projects in the region (Gallagher and Porzecanski 2009).

Extractivism in Ecuador became a strategic political and economic project around which discourses of development and new forms of environmentally friendly extraction pivoted (Davidov 2013; Hogenboom 2012). The 2009 Mining Law marked the beginning of an era of large-scale mining promotion in the country, assigning eminent domain to the central government in commissioning mining projects of "strategic national interest" and overriding the authority of local governments to control the exploitation of non-renewable resources. A new materiality emerged in which nature was accounted by the central government as metals and minerals ripe for extraction and land was conceived as mining concessions. Mining projects were constituted as a form of private property superseding the rights of the Shuar and mestizos to control territory and resources. As such, the current material and discursive process of state deterritorialization transforms land into a mining territory and has resulted in hierarchical institutions with new meanings, interests and actors.

Currently, the Cordillera del Condor is experiencing a new process of deterritorialization, with the central state gaining a more direct institutional presence and regulatory power than in previous decades. Economic and political pressures are dictated by mining interests and influenced by the global market. Largescale mining reflects the new territoriality exercised materially through land appropriation and resource commodification, denoting the priority given by the central state to the recovery of territorial control by administering the use of mineral resources and bolstering mining activities. The Ecuadorian central state reinforces a homogeneous representation of a mining territory through centralized national planning, regulation of the access to and use of resources. Productive economic transformations take the form of an extractive enclave (Vela-Almeida 2018).

Political conflicts due to state deterritorialization have been reinvigorated in the Cordillera del Condor since the beginning of the 2000s. These conflicts reached their peak in 2006 with large demonstrations opposing the mining company in El Pangui, where the very large Mirador copper mine ${ }^{2}$, now run by the Chinese company ECSA, is located (Warnaars 2013a). During the same year, the Shuar also evicted the David Lowell Mineral Exploration mining installation as well as the staff of ECSA in the Panantza-San Carlos project in what was known as Centro Shuar Nankints. In 2016, the Nankints community was deemed to have trespassed on private land and the whole population was displaced. State coercion occurred through military occupation in areas contiguous to the Panantza-San Carlos project accompanied by forced evictions and the destruction of community infrastructure. To counteract resistance, the left-leaning national government stressed the importance of national control of strategic projects by emphasizing the importance of supporting mining projects for social investment and poverty alleviation.

The Cordillera del Condor, as a mining territory, became legible through efforts by the state to reduce complexity and embrace a technocratic analysis of spatial planning for the management of 'strategic resources.' The central state used planning guides, consultation processes, environmental impact assessments and maps introduced as scientifically neutral instruments for decision-making and territorial zoning. Such approaches underpin the depoliticization of the state mechanisms in advancing specific patterns of deterritorialization

\footnotetext{
2 https://ejatlas.org/conflict/mirador-cordillera-del-condor-ecuador
} 
(Ferguson 1994; Li 2007). These instruments are built upon legible forms of environmental management that legitimate certain socio-environmental realities and incorporate agendas supporting environmentally- and socially-responsible development projects where 'risks' have been assessed (Habermas et al. 1984; Li 2009).

Legible instruments in the Cordillera del Condor result in the treatment of land and labor as convenient inputs ripe for capital accumulation within a global market economy. Territorial planning is perhaps the most ideal way to examine the ways in which socio-spatial relations are transformed, and nature becomes commodified. In Ecuador, territorial planning is conducted by promoting systems for decentralization through the development of the Plans for Development and Territorial Order (PDOTs in Spanish). PDOTs are participatory planning instruments established by subnational governments that define objectives and actions for local territorial development, supposedly reflecting local realities in the use of natural resources. However, studies conducted by Leifsen (2017) and Sánchez-Vázquez and Leifsen (2019) in the Cordillera del Condor illustrate that the PDOTs show a specific format to guide planning according to national priorities and to exclude other alternative local development efforts.

Although territorial planning constitutes nuanced mechanisms of direct state intervention by delimitating priorities for development, community planning vis-a-vis state planning has appeared as another form of 'mirror strategy' resistance to state control over territory (Sánchez-Vázquez and Leifsen 2019; Sánchez-Vázquez and Reyes 2017). The development of the PDOTs has become key in defining resource management, and local proposals for policies have included approaches that consider plural, incommensurable and incomparable forms of valuing resources and development strategies. In the case of Tundayme, where the Mirador project is located, the development of the last PDOT included the participation of community leaders, environmental organizations and local state authorities who opposed the mining project. Their participation in the PDOTs generated an alternative economic model for Tundayme where large-scale mining was not an option for local development (Leifsen 2017; Sánchez-Vázquez and Leifsen 2019).

The Ecuadorian state has legitimized mining extraction as a manageable activity where environmental risks are manageable, thus rendering territory legible for entry into commodity markets. To do this, the state and mining companies centralize the production, access and management of information regarding socioenvironmental impacts of mining (Sánchez-Vázquez and Leifsen 2019). This "corporate science" (Kirsch 2014) legitimizes development projects by presenting environmentally friendly and socially responsible practices evaluated in Environmental Impacts Assessments and Environmental Management Plans as rigorous and objective scientific procedures (Li 2015, 2009). However, Sánchez Vásquez and Reyes (2017) explain that territorial resistance also advocates for obtaining independent scientific studies in order to formulate counterarguments, create legible spaces based on the same scientific procedures and to reshape power relations. As such, legal claims to halt mining projects have been developed using counterevidence that illustrates fundamental flaws in corporate Environmental Impacts Assessments in the Mirador and Panantza San Carlos projects, and that dispute scientific knowledge by using similar methodological techniques for data generation (Sacher 2011).

Mechanisms of participation have also been exercised by Shuar and mestizos to contest state deterritorialization. One of the most important mechanisms to claim participation in the extractive governance regime is the free, prior and informed consultation of Indigenous people inhabiting areas planned for development. The lack of consultation about current mining projects in the Cordillera del Condor constitutes a violation of collective rights. Indigenous organizations, communities and civil society organizations legally demanded protection from the Mirador project in 2013 and the Panantza-San Carlos project in 2019, but these actions have failed to halt mining projects. Some battles, however, have been relatively successful in consolidating public participation and mobilizing actors at different levels. For example, in another recent largescale mining project known as Rio Blanco, in the Andean province of Azuay, the court established a moratorium on development given the lack of a consultation process with the impacted communities. Moreover, because the consultation was obviated by the state, the local population began formulating independent, communal and informed referendums and hearings based on their own institutions (Riofrancos 2014). The case of the locality of Girón opposed to the mining project of Kimsakocha in Azuay is also relevant as it became the first territorial jurisdiction using a binding local popular consultation to reject metals mining. Indeed, the lack of the state effort 
to enforce formal public participation paradoxically provides more political visibility to affected populations as they mobilize their claims using existing legal tools (Leifsen et al. 2017; Schilling-Vacaflor et al. 2018;).

The political use of formal instruments for consultation, contestation of socio-environmental information and guides for planning designed by the state, are forms of reterritorialization in which the population watches over spaces of participation in order to create alternative possibilities for the use of resources and future development. PDOTs and consultation processes are not just procedural state mechanisms of administration, but ways to create political substance through reterritorializing state practices (Leifsen 2017). These mirror strategies generate new forms of resistance epistemologies in a multi-scalar fashion, in which particular territorial struggles connect with networks of broader political and economic resistance among actors contesting state policies that support mining (Vela-Almeida et al. 2018). In fact, it has never been just local people resisting; they have formed coalitions with other national and international actors with a differentiated language of confrontation, whether through law, science, media visibility or civil disobedience.

The switch in resistance epistemologies has also modified the language of contestation. Initial narratives against state deterritorialization centered directly on large-scale extractivism because of its devastating impacts; nowadays, narratives focus on self-determination, Indigenous rights and the protection of nature and culture. The latter refer specifically to ancestral territorial claims based on the protection of collective rights and the rights of nature. The defense of collective rights has resulted in some communities reinforcing their Indigenous politico-cultural identities. The case of the Comunidad Amazónica de Acción Social Cordillera del Condor CASCOMI is an example of opposition to mining activities and therefore, state deterritorialization. This community was constituted originally as a union of several private property owners opposed to the Mirador mining project. In order to protect their land and fight eviction, they attained Indigenous status by selfidentifying as a Shuar Indigenous and mestizo community, effectively merging their prior individual properties to become communal land. Indigenous and non-Indigenous people alike thus adopted inventive legal strategies, and most importantly a new subjectivity to claim collective rights in order to protect their communal land.

This example illustrates how people find new forms of resistance. They maneuver their politico-cultural identities to claim rights, protecting themselves against support of mining by the national government. Reterritorialization against the unilateral production of a mining territory results in the reinforcement of Indigenous identities for the protection of collective rights, ancestral lands, livelihoods and self-determination. Indeed, identity-building has required continual transformation with subjects renegotiating alignment with, or confronting, deterritorialization. New subjects are thus created by and for the production of a form of territoriality, or indeed its rejection. Politico-cultural identities within a territory are built, above all, upon state sovereignty and the degree to which the state claims authority over both the people and resources (Peluso 1992). In other words, the definition of rights is determined from citizen identification where people have rights only if they are citizens of the nation and are ready to assume state-respecting responsibilities when called upon. Still, such current demands based on differentiated politico-cultural identities in the Cordillera del Condor respond to the subjective formation of citizens in their multiple and differentiated identities.

\section{Conclusion}

This study has emphasized the historical production of territory in the Cordillera del Condor and explored multiple state deterritorialization practices over time, including the institutionalization of new sociospatial organization, the legibility of land and resources, the commodification of nature and the subjectification of people. I have illustrated the ways in which the production of territory is entwined with the emphasis of the state on specific key materialities that serve economic interests. Narratives about the Cordillera del Condor went from describing wildness, emptiness and open access, to perceived idle land for agricultural and livestock purposes, then territory important for national security and more recently as a contested space for biodiverse conservation and large-scale extraction. While, the state has continuously claimed the Cordillera del Condor as a space for economic development, mechanisms for state deterritorialization have popped up in resistance movements, as used by Shuar and mestizo peoples in their various struggles. This research illustrates how variegated processes of state deterritorialization simultaneously result in institutional hybrid arrangements 
transformed and adapted on the ground to claim and protect people's land (Anthias and Radcliffe 2015; Cleaver 2002).

State deterritorialization is not a totalizing process, since people use the same strategies in diversified arrangements and to contest particular socio-spatial relations (Anthias and Radcliffe 2015). Reterritorialization strategies therefore do not occur in a vacuum but rather act as hybrid institutions used to contest land use, decision-making and to control the capacity of the state and its neoliberal practices. Indeed, Armiero (2008: 65) stresses that "the language of resistance is not independent of the language of repression/coercion. In fact, they correspond." As such, this article contributes to the political ecology of extractivism in Ecuador by highlighting the problem of reifying a dichotomic formula between the actions of the state vs. the actions of the people in deterritorialization-reterritorialization struggles. Instead, I attempt to illustrate how the imbricated process of state mechanisms have been mirrored to strategically fortify social demands for rights, justice and decisionmaking based on mechanisms of state vigilance. The positionality, language and strategies used to reterritorialize space depend on the material experiences, discourses and emotional connections of actors consciously and unconsciously interacting within a particular shared space. It is thus necessary to be cautious about essentializing dichotomic constructions of state-society relations (Gupta 1995) or assuming market-led practices to be wholly the product of capitalist forces writ large in variegated territories. Anthias and Radcliffe (2015) argue that spaces that superficially appear to be experiencing neoliberal practices can become "not quiteneoliberal spaces" due to the messy and contradictory processes of neoliberal institutional implementation. Indeed, resistance in the Cordillera del Condor has been shaped using the same state tools that have transformed and appropriated the territory.

A relevant question arises whether the neoliberal state deterritorialization is a path of no return and whether mirror strategies are useful in defending the territory in the Cordillera del Condor. On the one hand, the political economy of global market capital forces modern states to align perceived national needs with neoliberal notions of territory while continuously producing new socio-spatial forms of organization. On the other hand, although the production of territory in the Cordillera del Condor is contingent on the historical struggles and contemporaneous national priorities, it is also certain that governance, imaginaries, identities and local practices adjust according to the political negotiations among actors and the reshaping of institutions implemented on the ground. Clearly, the deterritorialization-reterritorialization struggle is fought on an unbalanced terrain.

State and corporations have the political, institutional and economic power to set commodity production in motion by claiming the importance of strategic sectors for national and regional economic development. Contestation takes place from uneven starting positions, with the powerful actors centralizing control that suppresses protest. Mirror strategies aim to recover the political potential of state mechanisms as ways to negotiate and redefine territory, livelihoods and economies in re-politicizing state instruments. Even if reterritorialization strategies could be considered to be simply reactive to deterritorialization, they illustrate the capacity of Shuar, mestizos and allies to engage and display creative agency. These groups have persisted because reterritorialization strategies have allowed them to enhance their agency by using mirror strategies to maintain resistance in continuously inventive and nuanced ways. Strategies differ due to daily-life experiences, political baggage, varying perceptions of justice and injustice and possible solutions (Armiero 2008). Moreover, it is not only the creative strategies people construct but also the ways in which they understand and perceive struggles, including the less rational, more emotional attachments and historically contingent ways people interact with each other, that shape how territory gets defended in one way or another. More research is needed to understand whether mirror strategies influence the political realm of decision-making regarding use and control of natural resources, especially considering the asymmetries of power, knowledge and economic influence between actors.

Possibilities for influencing decision-making rely on the potential to convert procedural and administrative mechanisms from consultative spaces into concrete practices in the political realm. However, these mechanisms can only achieve relative success within the boundaries of new endeavors by capital in territories; they do not necessarily challenge a whole system of ways of living. It is therefore important to situate territorial struggle not as a condition of state deterritorialization practices but as a contestation in the terrain of epistemology. The challenge lies in sustaining transformation that politically and ideologically challenges the 
structural systems that make up the logic of capital. In that regard, people are neither passive victims nor fierce contestants of state practices; they represent a plural mix of perspectives and differentiated subjectivities. Reterritorialization strategies make clear that it would be a historical mistake, a theoretical omission and an unfitting research approach to solely see people as victims of state actions. Instead, it is important to see them as subjects with a profound sense of agency even as they are struggling within a disadvantageous terrain. Perhaps scholarship should not only center on the narratives and strategies for resistance, but also on the type of subject that resists, and their transforming possibilities for navigating state practices for capital accumulation. The lesson to learn is that we cannot politicize resistance and struggles without politicizing the actors who struggle.

\section{References}

Adger, W.N., T.A Benjaminsen, K. Brown and H. Svarstad. 2001. Advancing a political ecology of global environmental discourses. Development and Change 32(4): 681-715.

Agnew, J.A. 2013. Territory, politics, governance. Territory, Politics, Governance 1(1): 1-4.

Anthias, P. and S.A. Radcliffe. 2015. The ethno-environmental fix and its limits: indigenous land titling and the production of not-quite-neoliberal natures in Bolivia. Geoforum 64: 257-269.

Armiero, M. 2008. Seeing like a protester: nature, power, and environmental struggles. Left History 13(1): 5976.

Báez Rivera, S., P. Ospina Peralta and G. Ramón Valarezo. 2004. Una breve historia del espacio ecuatoriano. Quito: Consorcio CAMAREN.

Bebbington, A.J., D.H. Bebbington, J. Bury, J. Lingan, J.P. Muñoz and M. Scurrah. 2008. Mining and social movements: struggles over livelihood and rural territorial development in the Andes. World Development 36(12): 2888-2905.

Boelens, R., B. Duarte, R. Manosalvas, P. Mena, T. Roa Avendaño and J. Vera. 2012. Contested territories: water rights and the struggles over indigenous livelihoods. The International Indigenous Policy Journal 3(3): 1-15.

Braun, B. 2000. Producing vertical territory: geology and governmentality in late Victorian Canada. Cultural Geographies 7(1): 7-46.

Brenner, N. and S. Elden. 2009. Henri Lefebvre on state, space, territory. International Political Sociology 3(4): 353-377.

Brighenti, A.M. 2010. On territorology: towards a general science of territory. Theory, Culture \& Society 27(1): 52-72.

Castree, N. 2007. Neoliberal environments: a framework for analysis. Manchester Papers in Political Economy 4(7).

Centro de Derechos Económicos y Sociales - CDES. 2017. Pueblo Shuar Arutam y salvaguardas socioambientales. Desafíos del programa Socio Bosque y su futura articulación al Fondo Verde para el Clima. [accessed March $20 \quad$ 2019]. http://cdes.org.ec/web/wpcontent/uploads/2017/12/Informe_SocioBosque-digital.pdf

Chicaiza, G. and I. Yanez. 2013. The mining enclave of the Cordillera del Condor. In Healy, H., J. MartínezAlier, L. Temper, M. Walter and J.F. Gerber (eds.). Ecological economics from the ground up. London: Routledge.

Cisneros, P. 2011. ¿Cómo se construye la sustentabilidad ambiental? Experiencias conflictivas de la industria minera en Ecuador. Ph.D. Dissertation. Quito, Ecuador: FLACSO-Ecuador.

Cleary, D. 2001. Towards an environmental history of the Amazon: from prehistory to the nineteenth century. Latin American Research Review 36(2): 64-96.

Cleaver, F. 2012. Development through bricolage: rethinking institutions for natural resource management. London: Routledge. 
Cleaver, F. 2002. Reinventing institutions: bricolage and the social embeddedness of natural resource management. The European Journal of Development Research 14(2): 11-30.

Davidov, V. 2013. Mining versus oil extraction: divergent and differentiated environmental subjectivities in "Post-neoliberal" Ecuador. The Journal of Latin American and Caribbean Anthropology 18(3): 485-504.

Davidov, V. 2014. Land, copper, flora: dominant materialities and the making of Ecuadorian resource environments. Anthropological Quarterly 87(1): 31-58.

Delaney, D. 2005. Territory: a short introduction. Oxford: Blackwell.

Deleuze, G. and F. Guattari. 1988. A thousand plateaus: capitalism and schizophrenia. London: Athlone Press.

Elden, S. 2010. Land, terrain, territory. Progress in Human Geography 34(6): 799-817.

Erazo, J.S. 2013. Governing indigenous territories: enacting sovereignty in the Ecuadorian Amazon. Durham: Duke University Press.

Esteva, G. 2010. From the bottom-up: new institutional arrangements in Latin America. Development 53(1): 64-69.

Ferguson, J. 1994. The anti-politics machine: 'development', depoliticization and bureaucratic power in Lesotho. Minneapolis: University of Minnesota Press.

Ferguson, J. and A. Gupta. 2002. Spatializing states: toward an ethnography of neoliberal governmentality. American Ethnologist 29(4): 981-1002.

Fontaine, G. 2006. La globalización de la Amazonía: una perspectiva andina. Iconos 10(2): 25-36.

Forsberg, T. 2003. The ground without foundation? territory as a social construct. Geopolitics 8(2): 7-24.

Foucault, M. 1991. The Foucault effect: studies in governmentality. Chicago: University of Chicago Press.

Gallagher, K.P. and R. Porzecanski. 2009. China and the Latin America commodities boom: a critical assessment. PERI Working Papers 192: 1-27.

García Labrador, J. and J. Ochoa. 2020. Two ontologies of territory and a legal claim in the Ecuadorian Upper Amazon. Journal of Political Ecology 27: 496-516.

Gupta, A. 1995. Blurred boundaries: the discourse of corruption, the culture of politics, and the imagined state. American Ethnologist 22(2): 375-402.

Habermas, J., M. Redondo and M. Garrido. 1984. Ciencia y técnica como "ideología." Madrid: Tecnos.

Haesbaert, R. and G. Bruce. 2002. A desterritorialização na obra de Deleuze e Guattari. GEOgraphia 4(7): 722.

Haesbaert, R. 2013. Del mito de la desterritorialización a la multiterritorialidad. Cultura y representaciones sociales 8(15): 9-42.

Hale, C.R. 1997. Cultural politics of identity in Latin America. Annual Review of Anthropology 26(1): 567-590.

Harvey, D. 2005. The new imperialism. Oxford: Oxford University Press.

Higgins, V., J. Dibden and C. Cocklin. 2012. Market instruments and the neoliberalisation of land management in rural Australia. Geoforum 43(3): 377-386.

Hogenboom, B. 2012. Depoliticized and repoliticized minerals in Latin America. Journal of Developing Societies 28(2): 133-158.

Huxley, M. 2007. Geographies of governmentality. In Crampton, J.W. and S. Elden (eds.). Space, knowledge and power: Foucault and geography. Hampshire: Ashgate.

Kimerling, J. 2006. Indigenous peoples and the oil frontier in Amazonia: the case of Ecuador, Chevron Texaco, and Aguinda v. Texaco. New York University Journal of International Law and Politics 38: 413-474.

Kirsch, S. 2014. Mining capitalism: the relationship between corporations and their critics. Berkeley: University of California Press.

Kohl, B. and L. Farthing. 2012. Material constraints to popular imaginaries: the extractive economy and resource nationalism in Bolivia. Political Geography 31(4): 225-235.

Lefebvre, H. 1991. Critique of everyday life. London: Verso.

Lefebvre, H. and D. Nicholson-Smith. 1991. The production of space. Oxford: Blackwell. 
Leifsen, E. 2017. Procesos de planificación en el proyecto Mirador: entre "participación ciudadana" y resistencia anti-minera. In K. van Teijlingen, E. Leifsen, C. Fernández-Salvador and L. SánchezVásquez (eds.). La Amazonía minada: minería a gran escala y conflictos en el sur de Ecuador. Quito: Universidad San Francisco de Quito \& Ediciones Abya-Yala.

Leifsen, E., L. Sánchez-Vázquez and M.G. Reyes. 2017. Claiming prior consultation, monitoring environmental impact: counterwork by the use of formal instruments of participatory governance in Ecuador's emerging mining sector. Third World Quarterly 38(5): 1092-1109.

Li, F. 2009. Documenting accountability: environmental impact assessment in a Peruvian mining project. PoLAR: Political and Legal Anthropology Review 32(2): 218-236.

Li, F. 2015. Unearthing conflict: corporate mining, activism, and expertise in Peru. Durham: Duke University Press.

Li, T.M. 2007. The will to improve: governmentality, development, and the practice of politics. Durham: Duke University Press.

Li, T.M. 2005. Beyond "the state" and failed schemes. American Anthropologist 107(3): 383-394.

Little, P.E. 2001. Amazonia: territorial struggles on perennial frontiers. Baltimore: Johns Hopkins University Press.

Little, P.E. 2018. Territórios sociais e povos tradicionais no Brasil. Anuário Antropológico 28(1): 251-290.

Mader, E. 1999. Metamorfosis del poder: persona, mito y visión en la sociedad shuar y achuar (Ecuador, Perú). Quito: Editorial Abya Yala.

Colloredo-Mansfeld, R. 2009. Fighting like a community: Andean civil society in an era of Indian uprisings. Chicago: University of Chicago Press.

Marcella, G. 1995. War and peace in the Amazon: strategic implications for the United States and Latin America of the 1995 Ecuador-Peru War. DIANE Publishing.

Martin, P.L. 2011. Global governance from the Amazon: leaving oil underground in Yasuni National Park, Ecuador. Global Environmental Politics 11(4): 22-42.

Marton-Lefevre, J. 2007. Peace parks: conservation and conflict resolution. Cambridge, Mass: MIT Press.

Peluso, N.L. 1992. Rich forests, poor people: resource control and resistance in Java. Berkley and Los Angeles: University of California Press.

Perreault, T.A. 2002. Movilización política e identidad indígena en el alto Napo. Quito: Editorial Abya-Yala.

Pueblo Shuar Arutam. 2019. Nuestro territorio. [accessed January 6 2019]. http://www.puebloshuararutam.org/naturaleza4/

Radcliffe, S. and S. Westwood. 1996. Remaking the nation: identity and politics in Latin America. London: Routledge.

Raffestin, C. and S.A. Butler. 2012. Space, territory, and territoriality. Environment and Planning D: Society and Space 30(1): 121-141.

Restrepo, M. 1993. El problema de la frontera en la construcción del espacio amazónico. In L. Ruiz (ed.) Amazonía: escenarios y conflictos. Quito: CEDIME. Pp.149-166.

Riofrancos, T. 2014. Contesting extraction: state-making, democracy, and large-scale mining in Ecuador. Ph.D. Dissertation. Philadelphia, USA: University of Pennsylvania.

Robbins, P. 2001. Tracking invasive land covers in India, or why our landscapes have never been modern. Annals of the Association of American Geographers 91(4): 637-659.

Rubenstein, S. 2001. Colonialism, the Shuar Federation, and the Ecuadorian state. Environment and Planning D: Society and Space 19(3): 263-293.

Rubenstein, S. 2007. Circulation, accumulation, and the power of Shuar shrunken heads. Cultural Anthropology 22(3): 357-399.

Sacher, W. 2011. Revisión crítica del "Estudio de impacto ambiental de beneficio del proyecto minero de cobre Mirador de la empresa Ecuadcorriente, Ecuador". [accessed January $10 \quad 2019$ ]. 
https://www.accionecologica.org/mineria/impactos/1522-proyecto-mirador-revision-critica-de-loseiaas.

Sack, R.D. 1986. Human territoriality: its theory and history. Cambridge: Cambridge University Press.

Salazar, E. 1977. An Indian federation in lowland Ecuador. Copenhagen: International Work Group for Indigenous Affairs.

Sánchez-Vázquez, L. and M.G. Reyes. 2017. Producción de conocimiento científico en el mirador: procesos participativos frente a la ciencia corporativa. In K. van Teijlingen, E. Leifsen, C. Fernández-Salvador and L. Sánchez-Vasquez (eds.). La Amazonía minada: minería a gran escala y conflictos en el sur de Ecuador. Quito: Universidad San Francisco de Quito \& Ediciones Abya-Yala.

Sánchez-Vázquez, L. and E. Leifsen. 2019. Resistencia antiminera en espacios formales de gobernanza: el caso de CASCOMI en Ecuador. European Review of Latin American and Caribbean Studies 108: 65-86.

Sawyer, S. 2004. Crude chronicles: indigenous politics, multinational oil, and neoliberalism in Ecuador. Durham: Duke University Press.

Schilling-Vacaflor, A., R. Flemmer, and A. Hujber. 2018. Contesting the hydrocarbon frontiers: state depoliticizing practices and local responses in Peru. World Development 108: 74-85.

Scott, J.C. 1985. Weapons of the weak: everyday forms of peasant resistance. New Haven: Yale University Press.

Scott, J.C. 1998. Seeing like a state: how certain schemes to improve the human condition have failed. New Haven: Yale University Press.

Sivaramakrishnan, K. 1999. Modern forests: statemaking and environmental change in colonial eastern India. Stanford: Stanford University Press.

Shue, V. 1994. State power and social organization in China. In J.S. Migdal (ed.) State power and social forces: domination and transformation in the third world, Cambridge: Cambridge University Press. Pp. 65-88.

Svampa, M. 2008. Cambio de época. Movimientos sociales y poder político. Buenos Aires: Siglo XXI.

Svampa, M. 2019. Las fronteras del neoextractivismo en América Latina: conflictos socioambientales, giro ecoterritorial y nuevas dependéncias. Bielefeld University Press.

Thomas, J. and I. Hodder. 2001. Archaeologies of place and landscape. Archaeology Theory Today 3: 165-186.

van Teijlingen, K. and X. Warnaars. 2017. Pluralismo territorial e identidades en el conflicto minero en la Cordillera del Cóndor. In K. van Teijlingen, E. Leifsen, C. Fernández-Salvador and L. Sánchez-Vasquez (eds.). La Amazonía minada: minería a gran escala y conflictos en el sur de Ecuador. Quito: Universidad San Francisco de Quito \& Ediciones Abya-Yala.

Van Teijlingen, K., E. Leifsen, C. Fernández-Salvador and L. Sánchez-Vásquez. 2017. La Amazonía minada: minería a gran escala y conflictos en el sur de Ecuador. Quito: Universidad San Francisco de Quito \& Ediciones Abya-Yala.

Unión Internacional para la Conservación de la Naturaleza - UICN. 2012. Pueblo Shuar Arutam repasa el ejercicio de sus derechos. [accessed February 25 2019]. https://www.iucn.org/es/content/pueblo-shuararutam-repasa-el-ejercicio-de-sus-derechos.

Vaccaro, I., A.C. Dawson and L. Zanotti, L. 2014. Negotiating territoriality: spatial dialogues between state and tradition. In A.C. Dawson, L. Zanotti and I. Vacarro (eds.), Negotiating territoriality: spatial dialogues between state and tradition. London: Routledge.

Vandergeest, P. and N.L. Peluso. 1995. Territorialization and state power in Thailand. Theory and Society 24(3): 385-426.

Vela-Almeida, D. 2018. Territorial partitions, the production of mining territory and the building of a postneoliberal and plurinational state in Ecuador. Political Geography 62: 126-136.

Vela-Almeida, D., V. Kolinjivadi and N. Kosoy. 2018. The building of mining discourses and the politics of scale in Ecuador. World Development 103: 188-198.

Viatori, M. 2016. Rupture and the maintenance of indigenous alterity: crises, borders, and race in Ecuador, 1941-2008. Ethnohistory 63(3): 497-518. 
Warnaars, X. 2013a. Territorial transformation in El Pangui, Ecuador. Ph.D. dissertation. Manchester, UK: University of Manchester.

Warnaars, X. 2013b. Territorial transformations in El Pangui, Ecuador: understanding how mining conflict affects territorial dynamics, social mobilization, and daily life. In A.J. Bebbington and J.T. Bury (eds.). Subterranean struggles: new geographies of extractive industries in Latin America. Austin: University of Texas Press.

Warnaars, X. and K. Van Teijlingen. 2017. Territorialidades históricas e imaginarios amazónicos en la Cordillera del Cóndor. In K. van Teijlingen, E. Leifsen, C. Fernández-Salvador and L. Sánchez-Vasquez (eds.), La Amazonía minada: minería a gran escala y conflictos en el sur de Ecuador. Quito: Universidad San Francisco de Quito \& Ediciones Abya-Yala.

Zibechi, R. 2012. Territories in resistance: a cartography of Latin American social movements. Oakland: AK Press. 